\title{
Hout in sy brood! Iets oor Calvyn se Bybelgebruik
}

\author{
L F Schulze \\ Potchefstroomse Universiteit vir C H O
}

\begin{abstract}
Wood in his bread! Something about Calvin's use of Scriptures
\end{abstract}

In his discussion of the Lord's Supper Calvin refers in one instance (Inst 4.17.15) to Jeremia 11:19. In this article, attention is given to Calvin's representation of a part of the text. Says Calvin: 'The prophet complains that wood was placed in his bread, intimating that by the cruelty of his enemies his bread was infected with bitterness....' In the Revised Standerd Version Jeremia $11: 19 \mathrm{~b}$ reads: 'Come, let us destroy the tree with its fruit.' This discrepancy is explained by discussing the difficulties in translating the Hebrew, and some conjectures that have been proposed to overcome these difficulties.

\section{DIE PROBLEEM}

Die aandagtige leser van die Institusie, wat Calvyn se Skrifverwysings opvolg, stuit teen die einde van afdeling 15 van hoofstuk 17 van die laaste boek op 'n oënskynlik ernstige probleem: Hy kan die marginale teksverwysing nie in sy Bybel vind nie!

Calvyn is in hoofstuk 17 besig met 'n uiteensetting van die Nagmaal. Op hierdie bepaalde plek in sy betoog kritiseer hy die Rooms-Katolieke teoloë, wat 'n deel van Jeremia se profesie deur middel van allegorisering aanwend om die transsubstansiasie te bewys. Hy skryf soos volg:

En, soos een dwaling nou maar uit 'n ander een ontstaan, is 'n aanhaling uit Jeremia so onverstandig verdraai om die transsubstansiasie te bewys dat ek jammer is om dit hier weer te gee. Die profeet kla dat 
daar hout in sy brood is; daarmee gee hy te kenne dat die wreedheid van die vyand sy brood bitter gemaak het. So kla Dawid met 'n soortgelyke stylfiguur daaroor dat sy voedsel deur gal en sy drank deur asyn bederf is. Hulle wil hier dat Christus se liggaam allegories aan die kruishout vasgenael moet wees. 'Maar sommige van die skrywers van ouds het dit dan so verstaan.' Net asof hulle onverstandigheid hulle nie vergewe en hulle skande begrawe moes word nie, eerder as dat die skaamteloosheid bygevoeg word dat hulle gedwing word om met die egte bedoeling van die profeet te bots.

(Inst 4.17.15)

Die betrokke gedeelte van Jeremia wat hier ter sprake is, is volgens die kantlynverwysing, Jeremia 11:19 terwyl wat Dawid betref, na Psalm 69:22 verwys word. Laasgenoemde verwysing klop: Dawid praat inderdaad daar van gal en asyn. Wanneer Jeremia 11:19 oopgeslaan word, lees ons egter in die vertaling van 1953 die volgende: Maar ek was soos ' $n$ mak lam wat hulle lei om te slag; en ek het nie geweet dat hulle planne teen my beraam het nie: Laat ons die boom met sy vrugte verwoes, en laat ons hom uitroei uit die land van die lewendes, sodat aan sy naam nie meer gedink word nie. Die Nuwe Vertaling verskil nie veel hiervan nie: $E k$ was soos ' $n$ mak lam wat weggelei word om geslag te word. Ek het nie besef dat hulle teen my saamsweer nie. Hulle het gesê: 'Laat ons die boom met die sap in hom vernietig en hom uitroei uit die land van die lewendes, sodat niemand meer aan hom dink nie.'

Met mindere of meerdere variasie (wat nie nou ter sake is nie) is dit die lesing van Luther se vertaling, die Authorised Version, die Revised Standard Version, die Statevertaling en die Franse vertaling van $L$ Segond, om maar enkeles te noem. By geeneen is daar in die verste verte sprake van 'hout in die brood' nie!

Natuurlik is die eerste en voor die hand liggende konklusie dat ons hier met 'n foutiewe teksverwysing te doen het. As dit so is, moes die verskillende samestellers van uitgawes van Calvyn se werke en vertalers van die Institusie hierdie toedrag van sake al bemerk en dit aangestip het. Nêrens is daar egter 'n aanmerking dat hierdie verwysing verkeerd is en wát die regte teksverwysing moet wees nie. Dit maak die saak meteens baie meer gekompliseerd. Is daar ' $n$ uitweg uit die dilemma, of staan ons voor ' $n$ onoplosbare teenstrydigheid?

\section{DIE KONTEKS}

Die uitweg uit hierdie moeilikheid is om die verband waarin Calvyn se bespreking van hierdie teks staan, in ag te neem. Hy is hier gewikkel in 'n polemiek met Rooms-Katolieke teoloë, en hierdie teoloë het natuurlik nie enige vertaling van die 
Bybel gebruik nie. Hulle het net een gesaghebbende vertaling van die Bybel gehad, en dit is die Latynse vertaling van Hiëronimus, naamlik die Vulgaat. Die Vulgaat laat dan ook meteens die lig opgaan, want volgens hierdie vertaling sê die samesweerders teen Jeremia: Laat ons hout in sy brood sit (Mittamus lignum in panem eius).

Hiermee is alles egter nog nie opgeklaar nie, want die vraag is nou: Waar kom die Vulgaat aan 'n teks wat so radikaal van moderne vertalings afwyk? By nadere ondersoek blyk dit dat Hiëronimus sy vertaling nie uit die Hebreeuse teks gemaak het nie, maar hom deur die Septuagint laat lei het, soos so dikwels ook met die Vetus Latina, die ou Latynse vertalings uit die tweede eeu, die geval is. Die Septuagint (volgens Rahlfs se uitgawe, wat effens verskil van die teks in die Poliglot Bybel)

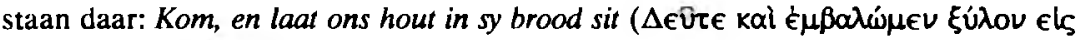

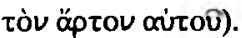

Die vertalers van die Septuagint het hulle by hierdie moeilike teks klaarblyklik op hulle beurt weer deels laat lei deur 'n ou tradisie, wat ook in die Targum van die Profete neerslag gevind het. Die Tangumteks wat in die Biblia Rabbinica (die Bomberg-uitgawe van 1525) opgeneem is, laat die betrokke sinsnede waarom dit hier gaan, weg. Die Targum Jonathan (Sperber 3:164) bied egter die variant van die werkwoord wat ook in die Septuagint voorkom. Die betrokke sinsnede lees in hierdie teks soos volg: Laat ons (ons sal) die sap van die dood in sy voedsel gooi (נרסי .

Wanneer in gedagte gehou word dat die Targums van die wet en die profete moontlik reeds in die vyfde eeu in Babel hulle finale beslag gekry het, en die geskrewe Aramees deur veel ouer mondelinge vertalings van die Hebreeuse teks voorafgegaan is (Robinson 1940:35-36), moet 'n mens aflei dat die betrokke gedeelte van die Jeremia-teks vroeg reeds problematies was of op sy minste onsekerhede bevat het wat moontlik op tekskorrupsie kan dui.

\section{DIE TEKS}

Die meeste moderne vertalings waarna hierbo verwys is, volg die Masorete-teks. Hierdie teks lees letterlik soos volg: Laat ons die boom met (in) sy brood verwors

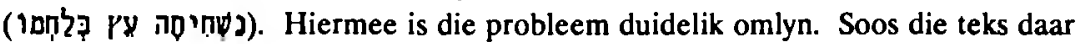
staan, maak dit nie goed sin nie. Die eenvoudigste uitweg is om brood as figuurlike spreekwyse vir vrug(te) te neem. Wanneer in ag geneem word dat $D$ b sowel 'brood' as 'kos' of 'voedsel' kan aandui (kyk Köhler \& Baumgartner), kan die sin van 'die boom en sy kos' sonder moeite verstaan word. Davidson (1945) gee dan ook onder $\square$ ל die betekenis 'vrugte' aan, met 'n verwysing na Jeremia 11:19. Dit is egter 'n vraag of hy nie hierdie betekenismoontlikheid van 'brood' juis uit die teks aflei nie 
en of so 'n afleiding gewettig is. In sy kommentaar op Jeremia meen Hyatt (1969: 913) dat dit onseker is of 'brood' wel 'vrug' kan beteken (Interpreter's Bible). Was dit die rede waarom die Targum die werkwoord geamendeer het om 'n beter lesing te verkry, of steun dit op 'n beter tradisie van die Jeremia-teks wat heel vroeg reeds beskadig kon gewees het? Op hierdie vrae is daar na my mening nie meer uitsluitsel te gee nie.

Die interessante toedrag van sake is dat daar wat hierdie sinsnede en sy vertaling betref, duidelik twee oplossings vir die moeilike lesing onderskei kan word:

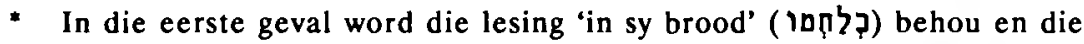
נרסי werkwoord van 'verwoes' na 'werp/gooi' gewysig. Wanneer die Aramese teruggeskryf word na Hebreeus, moes hier נל (hiph impf van -om te gooi) gelees word. Dit is die 'oudste' oplossing van die probleem, naamlik dié van die Septuagint en die Targum Jonathan. In dieselde lyn en nou verwant hieraan is die lesing van die Vetus Latina en die Vulgaat. Hier word mitto gebruik, wat ook die betekenismoontlikhede van 'werp', 'slinger', 'uitstuur', 'stuur' en 'loslaat' het. In sy tekskritiese aanmerkings ter plaatse meen Kittel dat die Hebreeuse lesing ניל (kal impf van -stuur, loslaat) hier veronderstel word. Dit maak aan die wesenlike betekenis van die sin nie verskil nie. Immers, dit maak geen verskil nie of 'n mens gif in die koffie 'gooi', en of jy dit daarin 'loslaat"!

- Die tweede oplossing is om die werkwoord van die Masorete-teks ("laat ons verwoes') te behou en 'in [met] sy brood' figuurlik op te neem as 'met sy vrugte'. Dit is die oplossing wat die meeste Bybelvertalings sedert die Reformasie gevolg het.

Daar is 'n derde oplossing wat deesdae baie veld wen en hier net interessantheidshalwe genoem word, omdat dit nie die posisie van Calvyn raak nie. Omdat dit onseker is of 'brood' inderdaad 'vrug[te]' kan aandui, het Hitzig (1969:913) 'n ander konjektuur voorgestel: om in plaas van $10 \prod ి$ ב heid) te lees (vgl Interpreter's Bible). Dit is 'n moontlike lesing wat sowel Köhler \& Baumgartner as die Biblia Hebraica Stuttgartensia voorstel. Botterweck, Ringgren \& Fabry voel so sterk vir hierdie lesing dat die Theologisches Wörterbuch zum Alten Testament onder die trefwoord ס לִ nie eers na Jeremia 11:19 verwys nie. Die teks word deur Fabry wel bespreek onder $\boldsymbol{n}$ (resp 0 ל.), en hy meen dat in sy sap/ varsheid' (בלהו) 'ein recht sinnfällige Metapher' is om die profeet in die fleur van sy lewe te teken (kyk Köhler et al 1983:533-534). Dit is die lesing waarvoor die Nuwe Vertaling gekies het. 


\section{TERUG BY CALVYN}

Hier waar Calyyn die Roomse allegorisering afwys, is hy sonder twyfel met die kanonieke Rooms-Katolieke teks, die Vulgaat, besig. Daarop wys die uitgawe van Barth \& Niesel (kyk Calvyn 1962:362, verw 1) met reg. Dit kom in die oorspronklike teks nog duideliker uit as in die vertaling. Die Latyn lees soos volg: Conqueritur Propheta lignum positum in pane suo (Calvyn 1962:362; my beklemtoning). Gelykluidend is die finale Franse teks van 1561: Le Prophete se plaind qu'on a mis du bois en son pain (Benoit 1961:393).

Hierdie sinsnede, sè Calvyn, beteken hoegenaamd nie dat die liggaam van Christus aan die kruishout vasgespyker moet wees nie. Om dit so allegories op te vat (al beroep hulle hulle daarvoor op die Kerkvaders), is niks minder as om die bedoeling van Jeremia te verdraai nie. Die blaps van die Kerkvaders kon liewer vergete en vergewe gewees het as om dit weer skaamteloos op te rakel. Ons moet die bedoeling van die profeet figuurlik verstaan: $\mathrm{Hy} \mathrm{kla}$ 'dat die wreedheid van die vyand sy brood bitter gemaak het'. Die Franse teks (kyk Benoit 1961:393) sê dit in 'n ander toonaard, naamlik dat sy vyande hom op wrede wyse die smaak van sy kos ontneem het (..que ses enemies luy ont cruellement osté le goust de son manger).

Calvyn was wars van alle allegorisering wat die eenvoudige sin van die Skrif verdraai. In sy kommentaar op 2 Korintiërs 3:6 is hy hieroor besonder uitgesproke. Hierdie gedeelte word as voetnoot in die Afrikaanse vertaling van die Institusie aangehaal en lui soos volg:

...dit is ' $n$ verderflike dwaling dat die mense gedink het dat Skriflesing nie alleen tevergeefs nie maar selfs skadelik sal wees, as dit nie tot allegorieë deurgetrek word nie. Hierdie dwaling was die oorsaak van baie euwels. Dit het immers nie alleen 'n losbandigheid om die egte betekenis van die Skrif te verkrag toegelaat nie, maar namate elkeen daarin brutaler was, is hy ook as 'n uitnemender verklaarder van die Skrif beskou.

(Calvyn 1986:465, verw 129)

Calvyn se verklaring lè in elk geval binne die verband van die sameswering teen Jeremia. Sommige vertalings sien hierdie sinsnede as 'n sameswering om die profeet geweldadig om die lewe te bring. Calvyn verklaar die Vulgaatteks in terme van die aanvanklike lyding wat hom toegebring word. Die toespeling op Psalm 69:22 skep 'n treffende analogie met die lyding, en daarna, die sterwe van Christus. In terme van die Hebreeuse poësie sou 'n mens kan sê: Calvyn sien nie die eerste twee strofes van Jeremia $11: 19 \mathrm{~b}$ as sinonieme parallelisme nie, maar as sintetiese parallelisme. 


\section{CALVYN SE JEREMIA-KOMMENTAAR}

Die kommentaar op Jeremia, en op die Klein Profete, was in werklikheid lesings (praelectiones) vir die teologiese studente. Vooraf word die teks of perikoop aangehaal wat verklaar gaan word. 'n Mens sou verwag dat Calvyn hom hier aan die teks van die Vulgaat gehou het, soos hy in die Institusie doen. Dit is egter nie die geval nie. Hy bied as't ware 'n 'mengvorm' van die twee oplossings vir die problematiese teks wat hierbo bespreek is: $\mathrm{Hy}$ behou die werkwoord van die Masorete-teks ('laat ons verwoes') en daarmee saam 'brood' in die letterlike betekenis! Dit beteken dat hy van die Vulgaat op hierdie punt afskeid neem en die Masorete-teks op die letter volg, maar tog ook nie konsekwent nie, want dit skep probleme. Daarom is hy verplig om in sy weergawe van die teks tussen hakies 'n onderskeid te makk tussen wat daar letterlik staan ('kom ons verderf hout in sy brood') en die 'sin' van die woorde, wat dan die regte vertaling is ('kom ons verderf sy brood met hout')."

Dit is nie moontlik om die hand te lê op al die Bybelvertalings wat tot Calvyn se beskikking was nie. Gevolglik kan nie bepaal word watter vertaling Calvyn hier gevolg het nie. Dit is egter ook bekend dat hy soms, as hy dit nodig geag het, geen bestaande vertaling gevolg het nie maar sy eie vertaling van die oorspronklike teks gegee het. 'n Byna identiese vertaling (afgesien van die werkwoord) word by Sebastian Münster gevind. Sy verklaring van die teks is egter anders: Hy sluit by die Targum aan en meld ten slotte dat die hout deur sommige as aanduiding van die kruis gesien word.**

In vergelyking met die Vulgaat is die laasgenoemde twee vertalings minder bevredigend, ten spyte van die Vulgaat se geammendeerde lesing van die werkwoord:

Vulgaat: ...mittamus lignum in panem eius....

Calvyn: ...corrumpamus ligno panem eius....

Münster: ..perdamus ligno panem ei is....

Die ablatiefvorm van 'hout' ( $a b l$ instrumentalis) vereis dat die Hebreeuse voorsetsel ook by 'hout' of 'boom' moes staan en nie by 'brood' nie. 'n Mens kan nie anders as om te konkludeer dat laasgenoemde twee vertalings ("volgens die sin van die woorde') geforseerd is nie.

- In die reeks Calvin's commentaries gee die vertaler, John Owen, die betrokke gedeelte van Calvyn se weergawe van Jeremia 11:19 soos volg weer: ...comumpamus ligno panera ejus (ad verbum est, cornimpamus lignum in pane; sed dicemus post de sensu verborum) et excidamus eum è terra vivonum...' (9, 2:109).

* Perdamus ligno panem eius. Hoc est, inficiamus cibum eius ligno venenato seu misceamus toxicum in vinum et cibum eius, sicut et Jonathan in hunc modum vertit: Immittamus venenum moriferum in cibos eius. Quidam ex nostris putant per lignum significari crucem et extremum supplicium; et per panem intelligunt vitam, quae per panem sustentatur (1546-uitgawe a l). 
Calvyn besef dit natuurlik ook terdeë. In sy verklaring hou hy hom dan ook eerstens met die teks as sodanig besig. Hy sê (en hier word Owen se vertaling aangehaal):

He then adds, Let us spoil wood in his bread. They think rightly, according to my judgment, who consider that there is here a change of case; for it ought rather to be, 'Let us spoil with wood his bread': for that exposition is too unmeaning, 'Let us spoil or destroy wood,' as though they spoke of a thing of no value: for what has this to do with the subject? On the contrary, if we retain, as they say, the letter, the Prophet might think that wood would be spoiled in bread, as it would become rotten: but wood in bread, except by becoming rotten, would do no harm.

(Calvyn 1979a:112)

Die oplossing is om die woorde as 'n metafoor te verstaan. Soos in die Institusie kom die verwysing na Psalm 69 ter sprake, nou aangevul met Klaagliedere 3:15. Anders as in die Institusie word die wreedheid van die vyande skerper geteken, naamlik dat hulle op elke manier sy vernietiging soek, selfs deur gif! Luister na Calvyn se redenering:

But doubtless the Prophet speaks here metaphorically, as David does in Psalm 69. 22, when he says, 'They have put gall in my bread and vinegar in my drink.' Jeremia also, in Lament. 3. 15, complains that his food was mingled with poison. Similitudes of this kind often occur; for when the very food of man is corrupted, there is no more any support for life. The meaning then is, that his enemies had acted cruelly towards the Prophet, as they sought in every way to destroy him, even by poison.

(Calvyn 1979a:112)

Tog twyfel Calvyn of hierdie woorde dui op 'n komplot om Jeremia te vergiftig. Hy weeg die moontlikheid, maar gaan dan tog nie die weg van die Targum en van Münster nie. Hy loop sy eie pad: verbittering van Jeremia se lewe met 'n implisiete afsnyding van wat sy lewe in stand hou. 
Some take wood for poison, but I know not whether that can be done. They indeed imagine that a poisonous wood is what is here meant; but this is too refined. I take the meaning to be simply this, as though they had said, 'Let us spoil with wood his food,' that is, 'Let us give him wood instead of bread; and this, by its hardness, will hurt his teeth, ulcerate his throat, and cannot be digested so as to become nourishment.' To spoil his bread with wood is to cause the wood to spoil the food either by its hardness or by its putridity. In this sense there is nothing ambiguous.

(Calvyn 1979a:112)

Wat hier opval, is die bondigheid en eenvoud van Calvyn se verklaring, die brevitas et facilitas wat moontlik 'n navolging van die bondigheid en eenvoud van die Skrif self is (vgl Gamble 1987). Dit, saam met die plastiese tekening van die gevolge van hout in die brood en die soek na 'n duidelike en ondubbelsinnige betekenis van die woorde, toon dat eksegese vir Calvyn nie (soos vir baie vandag) 'n bloot 'wetenskaplike' bedryf was nie, maar 'n noodsaaklike diens ten behoewe van die kerk.

\section{SLOT}

Calvyn het die selfgetuienis van die Skrif ernstig geneem. Daarom het hy op baie maniere en met baie beelde die feit dat God die 'Outeur' van die Skrif en van die 'hemelse leer' was, na vore gebring. Onr die vraag hoe Calvyn hom hierdie outeurskap voorstel en wat hy presies daaronder verstaan het, loop die menings van die biograwe en navorsers wyd uiteen. Calvyn moes al pa staan vir elke denkbare 'inspirasieteorie' wat in die eeue ná die Reformasie ontstaan het. Afhangende van die hoek waaruit hy (selektief) benader en geïnterpreteer word, is hy al gesien as die 'bron van die klassiek-Protestantse inspirasieteorie' (Seeberg), as die 'vader van die wetenskaplike Bybelkritiek' (Cramer), as verteenwoordiger van die grafiese (verbale) inspirasie (Ritschl), wat op 'die wyse van emanasie voorgestel' moet word (Noesgen). Les bes is hy iemand by wie daar van ' $n$ inspirasie by die teboekstelling van die Skrif geen sprake kan wees nie (Heppe; Doumergue; vgl vir die dokumentasie van die standpunte Krusche 1957:161-162). Dit laat 'n mens dink aan die lakonieke opmerking van Krusche (1957:161) by sy oorsig van alles wat aan Calvyn toegedig word: 'Man kann hier wirklich alles finden.'

Dit is ook geen wonder nie, want Calvyn het nie self 'n 'inspirasieteorie' ontwikkel en die geheimenisvolle werk van God rasioneel deursigtig probeer maak deur hom van die 'hoe' te probeer vergewis nie. Trouens, die term inspirare het ek in die verband van Calvyn se Skrifleer nog nie teëgekom nie. Calvyn gebruik die term wel 
in 'n algemene, nie-tegniese sin as hy in sy polemiek met Pighius sê dat die mens se neiging om vir homself te sorg en sy instink tot selfbehoud deur God in die mens 'geïnspireer' word (Schulze 1970:179, verw 32).

Die twyfelagtige eer om ' $n$ inspirasieteorie te ontwikkel, kom die teoloë van die (rasionalistiese) Ortodoksie van die sewentiende eeu toe. Dit was hulle taak om die Bybel formeel as 'gesagvolle boek' (sola Scriptura) teen Rooms-Katulleke aanvalle te verdedig. In hierdie proses moes daar dus rekenskap gegee word van die manier waarop die Bybel gesagvol is. So is die teorie van die 'verbale' inspirasie ontwikkel.

Eienaardig genoeg is daar geesgenote en welmenende konserwatiewe Christene, veral in die VSA, wat in die lyn van die 'liberale' Ritschl voortgaan en Calvyn as die vader van 'the high doctrine of plenary, verbal inspiration, espoused by the Reformed dogmaticians of the 17th century' sien (Murray 1982:158). Die probleem is dat hierdie 'rigidly orthodox verbal type of inspiration' (Kantzer, soos aangehaal deur Murray 1982:158) waarvan Calvyn die inisieerder sou wees, nie presies omskryf word nie. Dit bly meestal vaag, soos blyk uit Murray se toegewing: 'Calvin does recognize that the writers of Scripture were not always meticulously precise on certain details such as those of number and incident.' Hy erken: 'The Scripture abounds in illustrations of the absence of the type of meticulous and pedantic precision which we might arbitrarily seek to impose as the criterion of infallability', en stel dit duidelik: 'Scripture does not make itself absurd by furnishing us with pedantry' (Murray 1982:174). Tog vind hy in die voorbeelde van Calvyn se 'vrye' Skrifbeskouing wat hy bespreek het dat '...the language used by Calvin in these connections is ill-advised and not in accord with Calvin's usual caution when reflecting on the divine origin and character of Scripture' (1982:175).

'n Skrif wat 'verbaal' en gevolglik verbatim ingegee is, moet onvermydelik 'n vaste en onveranderbare teks hê. Dan is dit vreemd dat Calvyn sy eie konjektuur voorstel, naamlik dat die Hebreeuse voorsetsel van 'brood' na 'hout' verskuif word. Trouens, sy uitspraak, 'They think rightly, according to my judgment, who consider that there is here a change of case' kan kwalik iets anders as 'n verskuiwing van die Hebreeuse voorsetsel inhou. Die voorstanders van die verbale inspirasie en die foutloosheid ('inerrancy') van die Skrif sal hierop teëwerp dat Calvyn hier met 'n afskrif van die oorspronklike besig was, en deur dit te verander juis bewys dat hy in die foutloosheid van die outograaf glo. Kom ons gee dit vir 'n oomblik toe. Dan beteken dit dat volgens Calvyn se oordeel die outograaf, soos die Masorete-teks, verwoes' of 'verderf' gelees het. Maar dan is hierdie lesing gefikseer. Die outograaf, wat woordelik ingegee is, kan nie twee verskillende lesings van dieselfde teks toelaat nie. Hoe moet ons dit dan verklaar dat Calvyn in die Institusie die lesing van die 
Vulgaat gebruik sonder om die Rooms-Katolieke teoloë te verwyt dat hulle die Skrif verdraai deur 'stuur' in plaas van 'verwoes' te lees?

Calvyn pas eenvoudig in geen 'inspirasieteorie' nie. Hy is nie ad verbum ingestel, soos die verbale inspirasieteorie nie, maar de sensu verborum; dit gaan om die sin en betekenis van die Skrif, om wat God sê. Daarom is die terugprojektering van die latere inspirasieteorieë op Calvyn nie net 'n anachronisme nie; dit is ook vrugteloos.

Dat die Skrif deur God ingegee is, staan vir Calvyn vas. Die Heilige Gees het immers sy beeld op die Skrif afgedruk (Inst 1.9.2). Maar hoe Hy dit gedoen het, bly, soos al God se werke, vir ons onverklaarbaar. So bely ons dit ook in die Nederlandse Geloofsbelydenis, Artikels 3-7.

'n Mens dink hier aan Luther se disputasie teen die skolastieke teologie, waarin hy so fulmineer teen die sillogistiese bewysvoering in die teologie en sê dat wanneer ons iets kan bewys of rasioneel deursigtig kan maak, ons dit weet en dit dus nie meer hoef te glo nie.

Calvyn erken die Skrif in al sy menslikheid (Amos se styl, wat na die stal ruik!). Tog is dit op onverklaarbare maar ontwyfelbare wyse die spreke van God. Sy stem moet ons hoor, sy bedoeling moet ons verstaan, sy beloftes moet ons omhels en in sy vaderlike barmhartigheid moet ons rus.

\section{Literatuurverwysings}

\section{Bybels}

Biblia Hebraica 1951. Edidit R Kittel. Tiende druk. Stuttgart: Priviligierte Würtembergische Bibelanstalt.

Biblia Hebraica Stuttgartensia 1984. Ediderunt K Elliger et W Rudolph. Stuttgart: Deutsche Bibelgesellschaft.

Biblia Munsteriana 1546. Hebraica Biblia, latina planeque; nova Sebast. Munsteri translatione. Basileae.

Biblia rabbinica 1972. Edited by Jacob ben Hayim. Jerusalem: Makor. (Reprint of the 1525 Venice edition.)

Biblia sacra iuxta vulgatam versionem 1975. Tweede druk. Stuttgart: Würtembergische Bibelanstalt.

Bijbel 1899. Door last van de hoog mog. heeren Staten Generaal der vereenigde Nederlanden. Londen: Britsche en Buitenlandsche Bijbelgenootschap.

Bomberguitgawe: Kyk Biblia rabbinica.

Die Bibel 1899. In Dr. Luthers Uebersetzung. Konstanz: Christlicher Buch- und Kunstverlag K Hirsh. 
Die Bybel 1957. Vierde uitgawe. Kaapstad: Bybelgenootskap van Suid-Afrika.

--- 1984. Nuwe Vertaling. Derde druk. Kaapstad: Bybelgenootskap van Suid-Afrika.

La Bible 1974. Les sociétés Bibliques.

Polyglottenbibel 1864. Bearbeitet von R Stier \& K G W Thiele. Band 2,2. Bieleveld: Velhagen \& Klasing.

Septuaginta 1935. Edidit A Rahlfs. Editio nona. Stuttgart: Deutsche Bibelstiftung. The Bible 1972. Autorised Version. Oxford: The Bible societies.

--- 1952. Revised Standard Version. London: Collins.

The Bible in Aramaic 1962. Edited by A Sperber, vol 3. Leiden: Brill.

\section{Ander bronne}

Botterweck, G J, Ringgren, H \& Fabry, H-J (Hrsg) 1983. Theologisches Wörterbuch zum Alten Testament (ThWAT), Band 4. Stuttgart: Kohlhammer.

Brown, F, Driver, S R \& Briggs, C A (eds) 1974. A Hebrew and English lexicon of the Old Testament. Oxford: Clarendon.

Buttrick, G A (ed) 1969. The Interpreter's Bible, vol 5. New York: Abingdon-Cokesbury Press.

Calvyn, J 1961. Institution de la religion Chrestienne. Edition critique avec introduction, notes et variantes, publiée par J-D Benoit. Paris: Librairie philosophique J Vrin.

--- 1962. Joannis Calvini opera selecta, vol 5. Ediderunt $P$ Barth et $G$ Niesel. Editio secunda emendata. Monachi in Aedibus: Chr Kaiser.

-- 1979a. Commentaries on the book of the prophet Jeremiah and the Lamentations. Transl and ed by J Owen. Grand Rapids: Baker Book House. (Calvin's commentaries, vol 9.)

--- 1979b. Institutes of the Christian religion. Eighth impression. Transl by H Beveridge. Grand Rapids: Eerdmans.

--- 1986. Institusie van die Christelike godsdiens, Boek 2. Vertaal deur H W Simpson. Potchefstroom: Calvyn Jubileum Boekefonds. (Uit die nog ongepubliseerde boek 4 is met die vriendelike toestemming van die vertaler aangehaal.)

Davidson, B 1945. The analytical Hebrew and Chaldee lexicon. London: Bagster \& sons.

Gamble, R C 1987. Exposition and method in Calvin. Westminster Theological Journal 49/1, 153-165.

Köhler, L \& Baumgartner, W (eds) 1958. Lexicon in veteris testamenti libros. Leiden: Brill. 
Krusche, W 1957. Das Wirken des Heiligen Geistes nach Calvin. Göttingen: Vandenhoek.

Murray, J 1982. Collected writings of John Murray, vol 4. Edinburgh: The Banner of Truth Trust.

Robinson, H W (ed) 1940. The Bible in its ancient and English versions. Oxford: Clarendon.

Schulze, L F 1970. Die Skrifbeskouing van die Reformatore. HTS 26/3 \& 4, 170188. 